\title{
EFFECTS OF HIGH-PRESSURE WATER JETS ON ARMOURED SCALE INSECTS AND OTHER CONTAMINANTS OF HARVESTED KIWIFRUIT
}

\author{
D.C. WHITING ${ }^{1}$, L.E. HOY ${ }^{1}$, P.G. CONNOLLY ${ }^{1}$ \\ and R.M. McDONALD ${ }^{2}$
}

HortResearch, ${ }^{1}$ Private Bag 92169, Auckland; ${ }^{2}$ Private Bag 3123, Hamilton

\begin{abstract}
The potential of high-pressure water jets (HPJ) to kill or remove armoured scale insects and other insects and mites from the surface of harvested kiwifruit, and the capacity of a hot water pre-treatment (HWT) to enhance the HPJ effect was examined. Infested fruit were exposed to HPJ (0, 1000 or 2000 psi), either with or without HWT pretreatment (55 or $65^{\circ} \mathrm{C}$ for 30 seconds), and mortality and removal compared with fruit subjected to simulated standard packhouse brushing. The 1000 psi HPJ treatment did not dislodge scale insects, but the 2000 psi HPJ treatment resulted in increased incidence of partial removal. HPJ was more effective against all other contaminants present. Both HPJ and HWT alone caused high scale insect mortality. Although combination HWT with 2000 psi HPJ treatments were most successful against armoured scale, $\leq 17 \%$ of fruit were completely free of infestation after such treatment. By contrast, $\geq 99 \%$ of fruit were free of other contaminants after a combined treatment.

Keywords: armoured scale insects, contaminants, high-pressure water jets, hot water treatment, kiwifruit, disinfestation.
\end{abstract}

\section{INTRODUCTION}

Detection by Japanese inspectors of three armoured scale insects - greedy scale (Hemiberlesia rapax), latania scale (Hemiberlesia lataniae) and oleander scale (Aspidiotus nerii), and certain other arthropod pests on New Zealand kiwifruit, prompts methyl bromide fumigation of export shipments in Japan. Such fumigation is expensive (Harding 1993) and reduces the shelf life of the fruit by advancing ripening (Beever and Yearsley 1983). The frequency of fumigation could be reduced by decreasing the incidence of actionable pests on kiwifruit prior to export. Postharvest removal during packhouse processing is one way to achieve this. High-pressure water jets (HPJ) are used commercially overseas to dislodge red scale from citrus (Honiball et al. 1979; Walker et al. 1996). This paper describes trials assessing the potential of HPJ to remove armoured scale and other insects and mites from the surface of harvested kiwifruit. In addition, we determined if a short hot water pre-treatment enhances HPJ removal performance.

\section{Infested fruit}

\section{METHODS}

Scale-infested 'Hayward' kiwifruit were harvested from HortResearch, Kumeu, held at ambient temperature overnight, then graded (count 36 - 39) and packed into cartons, each lined with an insect proof bag. Fifty infested kiwifruit (2 fibre trays of 25 fruit) were allotted to each carton. Each carton was used for one replicate of a treatment. Fruit were then held for 2 days at $20^{\circ} \mathrm{C}$ prior to being transported to HortResearch, Ruakura for treatment.

High-pressure water jet equipment

The HPJ unit was comprised of rows of soft cup rollers which carried the fruit to the spray site, and three 25 degree fan jets directed at the fruit, the outer two at 45 Proc. 51st N.Z. Plant Protection Conf. 1998: 211-215 
degrees to the horizontal axis. Distances from the jet orifice to the nearest point of the fruit were 78 and $110 \mathrm{~mm}$ for the centre and side jets, respectively. The centre jet was angled to impact the fruit $10 \mathrm{~mm}$ behind the side jets, both to avoid interference between jets, and to aid the rotation of the fruit. Each fruit was exposed to jet impact for one second, completing two revolutions in this time.

\section{Treatment procedure}

Two hot water pre-treatments (HWT) and two HPJ treatments were tested either individually or in combination. For HWT, fruit were placed into a coarse mesh bag, immersed in hot water at 55 or $65^{\circ} \mathrm{C}$ for 30 seconds then immersed in ambient temperature water for 10 seconds to cool the fruit. For HPJ treatment, fruit were placed gently onto an infeed conveyer which carried it through the HPJ unit set at 1000 or 2000 psi, and then into a water dump. Fruit were held in the water dump for approximately 2 minutes, then fed by hand onto brushes which moved the fruit for 3 minutes through an air drier at $55^{\circ} \mathrm{C}$. Three replicates of each treatment combination were performed. Nine replicates of the packhouse control, which was exposed to 3 minutes of dry brushing only, were executed. Following treatment, fruit were repacked onto trays, held in ambient air for 30 minutes, then placed into insect proof bags inside new cartons. Three replicates of 45 untreated fruit were selected as orchard controls. All fruit was transported to HortResearch, Auckland, and stored at $12 \pm 1^{\circ} \mathrm{C}$ until assessment 5 to 7 days later.

\section{Assessment}

Assessment was carried out using a binocular microscope (2-40x magnification). The kiwifruit surface was marked into quarters with a pen and the location (cheek, stem, calyx) and survival of every armoured scale insect assessed. A scale insect was scored 'live' if the body was yellow and turgid when the cap was lifted with a pin. By contrast, the body of a 'dead' scale insect appeared brown and dehydrated. The location and number of basal plates (= remains of a scale insect with the body and cap missing) were also scored. Although non-viable, the incidence of these "partially removed' insects was an indicator of minor treatment effects. In addition, the incidence of other insect and mites was noted.

\section{Statistical analyses}

The mean number of armoured scales per fruit was calculated using the Generalized Linear Model procedure (Chambers and Hastie 1992) in S-PLUS (Statistical Sciences Inc. 1996) to analyse the data for each fruit location. The model assumed that the variance was proportional to that of a Poisson distribution. Fitted values for the HWT/ HPJ treatments were compared with those for the packhouse control. Because there was no discernible location effect, total numbers per fruit only are presented.

Standard errors used to calculate $95 \%$ confidence intervals (CI) are based on fruit to fruit variation in the insect numbers for each treatment. Significant differences are reported at the $5 \%$ probability level.

The percentage dead scale insects presented is the number of dead armoured scale relative to the total number observed on each fruit for each treatment. Averages and 95\% CIs were calculated on an arcsine scale and back-transformed to percentages.

\section{Armoured scale insects}

\section{RESULTS}

Armoured scale species were the most abundant arthropod contaminant on the kiwifruit in the orchard (Tables 1 and 2). Half of the scale insects recovered after simulated packhouse processing were dead (Table 1). Packhouse processing failed to remove armoured scale insects.

HPJ treatment alone caused significant armoured scale mortality when compared to the packhouse control (Table 1). The 1000 psi treatment did not remove scale insects. However, HPJ at 2000 psi resulted in a significant increase in the percentage of basal plates only present.

HWT alone also caused armoured scale mortality. No scale insects survived the $65^{\circ} \mathrm{C} \mathrm{HWT}$. However, HWT neither reduced the number of scale insects on the fruit, nor increased the percentage of clean fruit. 
TABLE 1: Mean number per fruit, percentage dead, percentage removal, percentage of basal plates only and percentage fruit clean of armoured scale insects $(95 \%$ CI ) after simulated packhouse processing or HPJ with or without HWT pre-treatment.

\begin{tabular}{|c|c|c|c|c|c|}
\hline Treatment & No. per fruit & $\%$ dead & $\begin{array}{l}\text { Total } \% \\
\text { removal }\end{array}$ & $\begin{array}{l}\% \text { basal } \\
\text { plates }\end{array}$ & $\begin{array}{l}\text { Mean } \% \\
\text { clean fruit }\end{array}$ \\
\hline Orchard control & $\begin{array}{l}18.4 \\
(13.9-22.9)\end{array}$ & NR & - & 0 & 0 \\
\hline Packhouse control & $\begin{array}{l}13.8 \\
(10.9-16.6)\end{array}$ & $49(45-53)$ & $25(1-49)^{\mathrm{a}}$ & 0 & $2(0-4)$ \\
\hline 1000 psi HPJ & $\begin{array}{l}14.0 \\
(9-18.9)\end{array}$ & $77(72-83)$ & $-1(0-40)^{b}$ & $2(1-4)$ & $5(0-11)$ \\
\hline 2000 psi HPJ & $\begin{array}{l}10.4 \\
(6.2-14.5)\end{array}$ & $86(81-90)$ & $25(0-58)^{\mathrm{b}}$ & $7(5-11)$ & $10(4-16)$ \\
\hline $55^{\circ} \mathrm{C} \mathrm{HWT}$ & $\begin{array}{l}11.2 \\
(6.8-15.6)\end{array}$ & $88(84-91)$ & $19(0-56)^{\mathrm{b}}$ & $1(0-2)$ & $4(0-8)$ \\
\hline $65^{\circ} \mathrm{C} \mathrm{HWT}$ & $\begin{array}{l}10.3 \\
(6.1-14.5)\end{array}$ & 100 & $25(0-58)^{\mathrm{b}}$ & $1(1-2)$ & $5(1-9)$ \\
\hline $\begin{array}{l}55^{\circ} \mathrm{C} \mathrm{HWT}+ \\
1000 \text { psi HPJ }\end{array}$ & $\begin{array}{l}11.9 \\
(7.3-16.5)\end{array}$ & $95(92-97)$ & $14(0-51)^{\mathrm{b}}$ & $3(2-5)$ & $9(5-13)$ \\
\hline $\begin{array}{l}65^{\circ} \mathrm{C} \mathrm{HWT}+ \\
1000 \text { psi HPJ }\end{array}$ & $\begin{array}{l}12.1 \\
(7.3-16.9)\end{array}$ & 100 & $12(0-51)^{b}$ & $5(3-9)$ & $11(3-19)$ \\
\hline $\begin{array}{l}55^{\circ} \mathrm{C} \mathrm{HWT}+ \\
2000 \text { psi HPJ }\end{array}$ & $\begin{array}{l}5.5 \\
(2.3-8.6)\end{array}$ & $94(92-97)$ & $60(36-84)^{b}$ & $8(4-12)$ & $17(15-19)$ \\
\hline $\begin{array}{l}65^{\circ} \mathrm{C} \mathrm{HWT}+ \\
2000 \text { psi HPJ }\end{array}$ & $\begin{array}{l}7.3 \\
(3.8-10.8)\end{array}$ & 100 & $47(20-74)^{\mathrm{b}}$ & $15(11-20)$ & $9(5-13)$ \\
\hline
\end{tabular}

${ }^{\text {a }}$ Removal relative to orchard control.

${ }^{\mathrm{b}}$ Removal relative to packhouse control.

$\mathrm{NR}=$ not recorded

Combination of HWT with 1000 psi HPJ treatment enhanced mortality at $55^{\circ} \mathrm{C}$, but did not improve removal over the best level expressed after either HWT or 1000 psi HPJ alone (Table 1). Combining $55^{\circ} \mathrm{C} \mathrm{HWT}$ with 2000 psi HPJ also resulted in a mortality greater than that characteristic of $55^{\circ} \mathrm{C} \mathrm{HWT}$ alone. There was a tendency for greater removal with HWT +2000 psi treatment combinations but this effect was masked by the large variation in the number of scale insects per fruit. The incidence of partial removal was increased by adding $65^{\circ} \mathrm{C} \mathrm{HWT}$ to the $2000 \mathrm{psi} \mathrm{HPJ}$ treatment. While combination HWT +2000 psi HPJ treatments appeared to be the most successful of those treatments tested for removing armoured scales, on average only $9-17 \%$ of fruit were completely free of scale insects after such treatments.

\section{Other contaminants}

Fifty three other organisms $(0.39$ / fruit $)$ were observed on the kiwifruit of the orchard control (Table 2), of which springtails, mites and thrips were the most common. Simulated packhouse processing did not reduce the number of these organisms on the fruit below that of the orchard control.

HPJ treatment alone was very effective for removing other insects and mites. While HWT alone also removed them, percentage removal was more variable. Both treatments resulted in a high percentage of clean fruit. Combination HWT + HPJ treatments resulted in $100 \%$ removal of other insects and mites and completely clean fruit, with the exception of 55(C HWT +2000 psi HPJ where one dead oribatid mite remained on a fruit after treatment. 
TABLE 2: Mean number per fruit, percentage removal and percentage fruit clean $(95 \% \mathrm{CI})$ of other insects and mites after simulated packhouse processing or HPJ with or without HWT pre-treatment.

\begin{tabular}{llll}
\hline Treatment & No. per fruit & $\begin{array}{l}\text { Total } \% \\
\text { removal }\end{array}$ & $\begin{array}{l}\text { Mean } \% \\
\text { clean fruit }\end{array}$ \\
\hline Orchard control & $0.39(0.26-0.51)$ & - & $79(65-93)$ \\
Packhouse control & $0.33(0.18-0.49)$ & $13(0-62)^{\mathrm{a}}$ & $79(75-83)$ \\
1000 psi HPJ & $0.01(0-0.04)$ & $96(86-100)^{\mathrm{b}}$ & $99(97-100)$ \\
2000 psi HPJ & $0.01(0-0.02)$ & $98(94-100)^{\mathrm{b}}$ & $99(97-100)$ \\
$55^{\circ} \mathrm{C}$ HWT & $0.04(0-0.11)$ & $87(65-100)^{\mathrm{b}}$ & $96(92-100)$ \\
$65^{\circ} \mathrm{C}$ HWT & $0.18(0-0.52)$ & $48(0-100)^{\mathrm{b}}$ & $98(96-100)$ \\
$55^{\circ} \mathrm{C}$ HWT +1000 psi HPJ & 0 & $100^{\mathrm{b}}$ & 100 \\
$65^{\circ} \mathrm{C} \mathrm{HWT}+1000$ psi HPJ & 0 & $100^{\mathrm{b}}$ & 100 \\
$55^{\circ} \mathrm{C}$ HWT +2000 psi HPJ & $0.01(0-0.02)$ & $98(94-100)^{\mathrm{b}}$ & $99(97-100)$ \\
$65^{\circ} \mathrm{C} \mathrm{HWT}+2000$ psi HPJ & 0 & $100^{\mathrm{b}}$ & 100 \\
\hline
\end{tabular}

${ }^{\text {a }}$ Removal relative to orchard control.

${ }^{\mathrm{b}}$ Removal relative to packhouse control.

\section{DISCUSSION}

Although HPJ caused some mortality of scale insects, removal of armoured scales by this method was poor. This result is disappointing given the overseas success of similar technology against scale insects on citrus (Honiball et al. 1979; Walker et al. 1996), and the fact that the water pressures used were high. The American study on navel oranges (Walker et al. 1996) found significant removal of armoured scale by standard packhouse processing and the addition of a washing treatment (325 - $525 \mathrm{psi}$ ) enhanced packhouse removal by $73.4-99.7 \%$. However, that study used a Freshgard 4000 system with 5-8 banks of nozzles, each bank comprising of 2 nozzle-bearing manifolds, using longer fruit exposure times (15 - 21 seconds). Commercial South African and Israeli descaling systems use similar, comparatively low water pressures for shorter exposure times (2 - 10 seconds) (Du Toit Pelser 1993; A. Woolf pers. comm.). The inability of our HPJ to remove scale insects may also reflect the different surface characteristics of citrus and kiwifruit. The surface of citrus is relatively smooth and waxy, while kiwifruit are covered in obstructive epidermal hairs.

Armoured scale insects were susceptible to HWT alone. The 30 second HWT pretreatment resulted in high levels of mortality. Mathematical equations derived from previous disinfestation work on some of the other contaminants found infesting kiwifruit, predict that $99 \%$ mortality of diapausing two-spotted spider mite (Lester $e t$ al. 1997), 5th instar lightbrown apple moth and mixed life stages of longtailed mealybug (Lester et al. 1995 ) would require $55^{\circ} \mathrm{C}$ HWT exposures of 2.5, 7.5 and 13 minutes, respectively.

Of the HWT + HPJ combinations tested, only those incorporating 2000 psi HPJ showed benefit for scale insect removal over the most effective constituent treatment alone. HWT appears to reduce the ability of armoured scales to adhere to the fruit and withstand a subsequent HPJ treatment with some removal properties. Given the high mortality induced by HWT pre-treatment, this suggests dead scale insects are easier for the HPJ to dislodge than live scale insects. Bedford (1990) reported similar results with a low pressure (218 psi) washer. However, Bedford (1990) and Walker et al. (1996) found no difference in live and dead armoured scale removal from citrus with treatments $>325 \mathrm{psi}$. In Israel, armoured scale infested citrus is routinely sprayed with insecticide to kill the scale insects and $0.5 \%$ citral oil to soften the corpses, prior to HPJ treatment (A. Woolf pers. comm.). In addition, two studies have noted that preharvest parasitism of scale insects appears to enhance the chances of removal by HPJ over unparasitized scale insects (Honiball et al. 1979; Walker et al. 1996). Since dead scale insects are more susceptible to HPJ treatment, this technology may be more effective 
following mineral oil sprays and biocontrol agents used for armoured scale control. A delay between the HWT and HPJ components may also enhance removal by enabling full manifestation of HWT-induced mortality. HWT could be applied commercially prior to the mandatory curing to control stem-end rots, and be followed by HPJ treatment.

Removal success of HPJ (with or without HWT pretreatment) against other surface dwelling insects and mites on kiwifruit was excellent. Further work should examine the potential of lower water pressure HPJ to remove these organisms and assess the tolerance of export cultivars to effective HPJ treatments.

\section{ACKNOWLEDGEMENTS}

We thank W.S. Blyth, K.A. Lyall, K.J. Spooner, M. Lay-Yee, S.E. Lewthwaite, and P.S. Stevens for technical assistance. This work was funded by Zespri International contract 001-0004-97 and the New Zealand Foundation for Research, Science and Technology.

\section{REFERENCES}

Bedford, E.C.G., 1990. Mechanical control: high-pressure rinsing of fruit. Pp. 507513. In: The Armored Scale Insects, Their Biology, Natural Enemies and Control, Vol. B, D. Rosen (Ed); Elsevier, Amsterdam.

Beever, D.J. and Yearsley, C.W., 1983. Kiwifruit fumigation. DSIR Division of Horticulture and Processing Report. 7 pp.

Chambers J.M., Hastie, T.J., 1992. Statistical Models in S. Wadsworth and Brooks/ Cole, Pacific Grove, California.

Du Toit Pelser, P., 1993. Prevention of post-harvest Cladosporium sooty mould development on descaled citrus fruit. Citrus J. 3: 23-25.

Harding, R., 1993. A pioneering year in Japan. N.Z. Kiwifruit April/May: 5.

Honiball, F., Giliomee, J.H. and Randall, J.H., 1979. Mechanical control of red scale Aonidiella aurantii (Mask.) on harvested oranges. Citrus Subtrop. Fruit J. 549: 17-18.

Lester, P.J., Dentener, P.R., Petry, R.J. and Alexander, S.M., 1995. Hot-water immersion for disinfestation of lightbrown apple moth (Epiphyas postvittana) and longtailed mealybug (Pseudococcus longispinus) on persimmons. Postharv. Biol. Technol. 6: 349-356.

Lester, P.J., Dentener, P.R., Bennett, K.V. and Connolly, P.G., 1997. Postharvest disinfestation of diapausing and nondiapausing twospotted spider mite (Tetranychus urticae) on persimmons: hot water immersion and coolstorage. Ent. Exp. et Applic. 83: 189-193.

Statistical Sciences Inc., 1996. S-PLUS User's Manual, version 3.2, Statistical Sciences Inc., Seattle, Washington.

Walker, G.P., Morse, J.G. and Arpaia, M.L., 1996. Evaluation of a high-pressure washer for postharvest removal of California red scale (Homoptera: Diapididae) from citrus fruit. J. Econ. Ent. 89: 148-155. 